\title{
The Realistic Implication in Bernard Shaw's Pygmalion
}

\author{
Gong Fangming ${ }^{1, *}$
}

\author{
${ }^{1}$ The School of Literature, Hunan University, the Southern Lushan Road, Changsha, Hunan, China \\ *996985750@qq.com
}

\begin{abstract}
George Bernard Shaw is a prolific writer in the west who wins the Nobel Prize in 1925. As an Irish outsider in English society initially, he fights his way into the literary centre in England. His work Pygmalion is, somehow, an indirect representation of his personal growth and reflects his understanding of his time, especially his concern for the reality of the lower class. Pygmalion is about the transformation of a flower girl in the underclass. Higgins, a linguist, runs across Liza, a flower girl, and Pickering in the street. He boasts he can transform the "ragamuffin" of a flower girl into an exquisite duchess. The two men are later engaged in the bet that Higgins can live up to his brag. Higgins wins the wager, but not the respect of Liza. The New Liza, being independent of Higgins, declares that she will leave Higgins and maintain her present social status by teaching phonetics. Since its publication, Pygmalion has been adapted to the film and the musical version. The two adapted versions boost the popularity of Pygmalion, but they disappoint Bernard Shaw, who thinks that both the film and the musical miss his realistic implication. Shaw's original play is more insightful than the film and the musical and conveys far-reaching significance. Shaw is never a sentimental playwright. The play's attention in the myth Pygmalion shows the writer's strong desire for social reforms. That's why Shaw is a famous member of the English Fabian Society, which endeavours to carry forward social reform. With the realistic ending, Shaw does not intend Pygmalion to arouse the audience's strong emotion as much as to be didactic, to inspire the audience to meditate over the fact that the economy has the highest say in social life in this economic society. However, he does not agree with the decay of morality. With this in his heart, Shaw, along with Ibsen, initiates a revolution in drama: they use drama to represent social reality, to broadcast their social ideas, and to inspire the audience to realise these ideas.
\end{abstract}

Keywords: Bernard Shaw, Pygmalion, realism

\section{THE BACKGROUND OF PYGMALION AND ITS AMBIGUOUS ADAPTATIONS}

George Bernard Shaw is a prolific writer in the west who wins the Nobel Prize in 1925. As an Irish outsider in English society initially, he fights his way into the literary center in England. His work, "Pygmalion", a Romance in $\mathrm{V}$ Acts, is, somehow, an indirect representation of his personal growth and reflects his understanding of his time, especially his concern for the reality of the lower class. [1]

Pygmalion is about the transformation of a flower girl in the underclass. Higgins, a linguist, runs across Liza, a flower girl, and Pickering in the street. He boasts he can transform the "ragamuffin" of a flower girl into an exquisite duchess. The two men are later engaged in the bet that Higgins can live up to his brag. Higgins wins the wager, but not the respect of Liza. The New Liza, being independent of Higgins, declares that she will leave Higgins and maintain her present social status by teaching phonetics.

Since its publication, Pygmalion has won much attention. Although he persistently rejected offers from filmmakers, Shaw, impressed by the ardour and ability of Gabriel Pascal, eventually agreed to make a film of the play. The film, released in 1938, was a notable success. [2] This Irish playwright now had a large audience. The musical, My Fair Lady, is adapted from Shaw's Pygmalion. [3] In 1956, this musical opened in New Heaven, Connecticut. It has been a spectacular success ever since. In 1964, the film version of Shaw's Pygmalion won an Academy Award as best picture. The film and the musical boost the popularity of Pygmalion, but they 
disappoint Bernard Shaw, who thinks that both the film and the musical miss his realistic implication.

The film and the musical emerge as typical sentimental romances with the same ending: Higgins and Liza eventually get married happily, which contradicts astonishingly with the original one. But the conclusion of the original is a realistic one: the New Liza bid farewell to Higgins' bully and pursues her dignity by attending to the financial need for her present social status. Although the ending in the movie and the musical version whereas is typical of an idealistic romance: the creator eventually marries his creation, which arouses emotional bravo of the sentimental audience, it simplifies the reality faced by the lower class and lacks the insight of realistic work. This thesis endeavours to analyse the realistic connotation from two aspects: the implication conveyed by the legend Pygmalion and the implication in Shaw's original ending.

\section{THE REALISTIC IMPLICATION IN THE LEGEND PYGMALION}

The title of Shaw's play, "Pygmalion", a Romance in V Acts, can be connected with an ancient Greek legend about Pygmalion. Pygmalion is a famous sculptor who was a misogynist and determined to live out his bachelor's life. But against his wish, he carved a statue so perfect that he fell in love with his creation. Driven by his ardour for his work, he prayed to Aphrodite, the goddess of love, that she might have Pygmalion's beloved creation come back to life. Aphrodite fulfilled his wish, and Pygmalion happily married his work, which he named Galatea. This myth echoes the long-cherished dream that the lovers should end in a union, and in the audience's mind, so would Shaw's "Pygmalion", Higgins, and his "Galatea", Liza. Therefore, the title "Pygmalion" seems to justifies the assumption of the movie and the musical that the play Pygmalion is a happy romance. The two adapted versions correspondingly make use of the legend's blissful meaning and wins the heart of sentimental audience.

However, George Bernard Shaw doesn't intend the above implication by Pygmalion. Although he named his play Pygmalion, the legend Pygmalion has a different meaning from the above assumption. For Shaw, Pygmalion is a God who brings transformation. To be specific, it's the transformation of identity, of social status. In the play, Higgins transformed the image of Liza from a flower girl to a duchess, and Liza eventually realised that she be a transformer either.

"You can't take away the knowledge you gave me. You said I had a fine ear than you can $\cdots \cdot . \cdot$. I'll advertise it in the papers that you duchess is only a flowergirl that you taught, and that she'll teach anybody to be a duchess just the same in six months for a thousand guineas". [1]
Transformer always symbolizes an active and dignified identity. When Liza becomes a transformer, she can be independent and get rid of Higgins' bully. Transformer, in this sense, implies the general progress in human life. This transformation is a more significant and satisfying wish than the happy union in a sentimental romance.

Transformation is not only Shaw's experience but the experience of his time. Shaw lives in the later period of Victorian society, the Edwardian Period, and the Georgian Period. In his time, many lower-class people grow to be middle-class members through their hard work and sagacity, just like Liza. Transformation is a common theme in many plays written by Shaw, such as Mrs. Warren's Profession, Widower's Houses, Major Babara. The main characters in these plays all experienced transforming their social status from lower class to middle class through their efforts. Shaw speaks highly of this aggressive spirit:

"Her(Mrs. Warren) vitality, her thrift, her energy, her outspokenness, her wise care of her daughter, and the managing capacity which has enabled her and her sister to climb from the fried fish shop down by the Mint to the establishment of which she boasts, are all high English social virtues ". [4] (p. 230)

In this sense, Shaw's play's central image, Pygmalion, signifies the historical trend that brings progress to many lower-class people and society. Shaw's play, "Pygmalion", a Romance in V Acts, is, therefore, a highly suggestive work, which conveys the writer's humanistic desire for the progress of the lower class.

\section{THE IMPLICATION IN SHAW'S ORIGINAL ENDING}

Confronted with a different ending of a sentimental romance, Shaw defends his original conclusion in the prose "Sequel". He stresses once again his original design that the marriage between Higgins and Liza can never happen. Shaw explains that he subtitles his play a "romance" because the technical meaning of "romance" refers to anything that is highly improbable. Although it is taken for granted that a romance suggests an eventual happy union between lovers, he does not intend this ending in Pygmalion. He will never let his creation, Liza, marry Higgins, a typical social misfit, to fulfill the whims of the sentimental audience, even though the sentimentalists outnumber the realistic audience to a great degree.

Firstly, Higgins is more than twenty years older than Liza. There is probably a generation gap between the two. Besides, Liza is aware that she is kind, intelligent, and beautiful enough to marry an upper-class member more desirable than her teacher. The heroine is, therefore, unlikely to form an intimate relation with the hero. 
Secondly, Liza refuses to remain the guinea pig to Higgins' linguistic study; she recognises that Higgins' linguistic experiments will always be the vital thing in his life. Higgins is far from an eligible husband. Besides, Higgins is determined to live out his life as a bachelor.

Thirdly, after gaining her independence, Liza does not want to endure Higgins' bullying, his condescending way of treating her. Higgins, as her creator, would always use her origin as a way to annoy her and bully her. The union between the superior creator and the inferior creation will be far from satisfactory. This is opposite to the legend.

Last, Liza has a sincere wooer, Freddy. She intends to marry Freddy because he is emotionally attached to her and would therefore treat her with respect. But Freddy is not capable enough to seek a livelihood. Hence she is thrilled by the idea that she can financially support herself and Freddy by teaching phonetics. This marriage is suitable for Liza, who attaches more importance to dignity than to material.

As a result, despite the fact that Higgins can easily support Liza, Higgins's age, character, and way of treating Liza make him less likely to be her husband. His relation to his creation, Liza, is too hierarchical to become an agreeable couple. In addition to that, Liza has a much more desirable wooer. The hero and heroine in Shaw's Pygmalion are destined to have an opposite ending to the legend.

Although the two can not get married, which may upset some sentimental readers, the play is a qualified success, with its witty dialogues, humorous scenes, a Cinderella romance, and especially Shaw's profound meditation over reality which upgrades the work to a classic.

In Shaw's time, capitalism has stepped into the imperialist stage. In this new stage, the economy has the highest say in every aspect of human life. However, in any former society, which was an ethical society, moral judgment preoccupies the mind of people, the poor and the wealthy. In the imperialist stage, Nietzsche announces God's death: the long-cherished faith in morality yields to economic needs. Against this background, Shaw walks out of the traditional Shakespearian perspective, which focuses on the moral side. With the influence of Marxist's Das Kapital, Shaw emphasizes the economy's decisive role in social life. He advocates that economy has an enormous impact on people's actions, especially that of the poor. At the same time, he points out that poverty is the most severe crime and that our first duty is to get away from poverty[5]. Shaw, therefore, advocates the materialist way of Froissart's knight.

"Froissart's knight, in placing the achievement of a good life before all the other duties - which indeed are not duties at all when they conflict with it, but plain wickedness - behave bravely, admirably, and in the final analysis, public spiritedly”. [4](p. 120)

Shaw intends his plays to preach these ideas. Pygmalion, with a Cinderella romance, illustrates Shaw's conviction. Liza, with her social snobbism, always makes not so noble but realistic choices. In act II, despite Higgins' trampling on her dignity, she chooses not to leave when Higgins promises her a wealthy life after that. The play ends up in Liza's final realisation that she can be economically independent of Higgins by teaching phonetics. Shaw wants the reader to be impressed by this eventual insight of Liza, which resolves her lingering worries about her social status. This conclusion demonstrates that it is not the character but the economy that qualifies one's middle-class membership. The economy has the highest say in social ranks.

As for whom Liza marries, it is not so vital. Therefore, no marriage takes place in the original, and this incurs the seeming "ambiguity". But it is because its ending is ambiguous, the play Pygmalion is distinguished rather than run-of-the-mill. If it ended with Liza in Higgins' arms, it would be a delightful comedy that follows a wellworn path to an expected conclusion. But the ending of Shaw's original play leaves the reader alert and stimulated.

Besides, when the play ends in Liza's parting with Higgins against his wish, it serves as a satire of middleclass morality. In the text, Higgins, an upper-class member, treats Liza as an object in his experiment and shows no respect. When Liza rebels against his bully, she said:

“oh, you are a cruel tyrant. I can't talk to you: you turn everything against me: I'm always in the wrong. But you know very well all the time that youre nothing but a bully. You know I can't go back to the gutter, as you call it, and that I have no real friends in the world but you and Colonel. You know very well I couldnt bear to live with a low common man after you two, and it's wicked and cruel of you to insult me by pretending I could. You think I must go back to Wimpole Street because I have nowhere else to go but father's. But dont you be too sure that you have me under your feet to be trampled on and talked down"[1].

This statement is a fierce attack against the indifference prevailing among the upper-class represented by Higgins.

\section{CONCLUSION}

Although the film and the musical wins much attention, Shaw's original play is more insightful and conveys far-reaching realistic significance. Shaw is never a sentimental playwright. The play's attention in the myth Pygmalion shows the writer's strong desire for social reforms. That's why Shaw's a famous member of the 
English Fabian Society, which endeavours to carry forward social reform. With the realistic ending, Shaw does not intend Pygmalion to arouse the audience's strong emotion as much as to be didactic, to inspire the audience to meditate over the fact that the economy has the highest say in social life in this economic society. However, he disagree with the decay of morality. With this in his heart, Shaw, along with Ibson, initiates a revolution in drama: they use drama to represent social reality, to broadcast their social ideas, and to inspire the audience to realise these ideas.

\section{REFERENCES}

[1] Shaw, Bernard, Pygmalion: a Romance in Five Acts, Longman Group Ltd., 1981, pp. 103.

[2] Asquith, Anthony, and Leslie Howard, dir. Bernard Shaw's Pygmalion 1938, 2011. Doi: http://v.pptv.com/show/XA4Xlf1j0xF08vw.html

[3] Kukor, George, dir. My Fair Lady. 1964. Doi: http://www.tudou.com/programs/view/bvuBi4wRR $\mathrm{VU} /$

[4] Shaw, Bernard, Prefaces, Constable and Company Ltd., 1934, pp. 230, 120.

[5] Shaw, Bernard, The Ana of Bernard Shaw, Gansu People's Press, 1991, pp. 19. 